\title{
Physicochemical characterization, bioactive compounds and antioxidant activity of pulp, peel, endocarp and food paste developed with buriti pulp and waste (Mauritia flexuosa L.)
}

Caracterização físico-química, compostos bioativos e atividade antioxidante de polpa, casca, endocarpo e pasta alimentar desenvolvidos com polpa de buriti e resíduos (Mauritia flexuosa L.)

\author{
F. C. Cardoso ${ }^{1 *}$; A. P. S. Costa ${ }^{1}$; A. C. S. Crispino ${ }^{1}$; A. P. R. Silva ${ }^{2}$; J. A. R. \\ Oliveira $^{1}$
}

${ }^{1}$ Laboratório de Higiene de Alimentos e Bioprocessos, Faculdade de Nutrição, Universidade Federal do Pará, 66075 110, Belém-Pará, Brasil

${ }^{2}$ Escola Superior da Amazônia (ESAMAZ), 66053-180, Belém-Pará, Brasil

*johnattrocha@yahoo.com.br

(Recebido em 15 de junho de 2020; aceito em 25 de novembro de 2020)

\begin{abstract}
Buriti (Mauritia flexuosa L) is an Amazonian fruit with high potential to be used as a source of bioactive compounds and healthy food preparations due to its attractive yellow / orange color. The purpose of this paper was to verify the physicochemical characteristics, bioactive compounds and antioxidant activity in pulp, endocarp, peels, and three food paste developed with Buriti pulp and waste. In addition to the centesimal composition of the fractions of the fruit and the preparations, analyzes of vitamin $\mathrm{C}$, phenolic compounds, carotenoids and antioxidant activity were also carried out. The following values were observed for the fractions of the fruit: vitamin C (48.44-55.22 mg/100 g), carotenoids $(6.05-21.03 \mathrm{mg} / 100 \mathrm{~g})$, Total phenolics (19.31-33.30 mg GAEq/100g) and antioxidant activity (111.24-190.43 $\mu \mathrm{mol} \mathrm{TE} / \mathrm{g} \mathrm{DM})$, for all analyzed parameters, the highest values were observed for the peel. As for the formulations, it was found that the good attributes of the peel interfered in the formulation $\mathrm{C}$, which presented the highest yields of vitamin $\mathrm{C}(21.22$ $\mathrm{mg} / 100 \mathrm{~g})$, carotenoids $(13.99 \mathrm{mg} / 100 \mathrm{~g})$, Total phenolics $(21.45 \mathrm{mg} \mathrm{GAEq} / 100 \mathrm{~g})$ and antioxidant activity (82.34-130.52 $\mu \mathrm{mol} \mathrm{TE} / \mathrm{g} \mathrm{DM})$. Thus, it is verified that buriti has a great nutritional potential for direct consumption or to be used in the formulation of confectionery products, including the use of its peels in formulations.
\end{abstract}

Keywords: buriti, phenolic compounds, food paste

O Buriti (Mauritia flexuosa L) é uma fruta da Amazônia com alto potencial para ser utilizada, como fonte de compostos bioativos e preparações alimentares saudáveis devido à sua atraente cor amarela / laranja. O objetivo deste trabalho foi verificar as características físico-químicas, compostos bioativos e atividade antioxidante em polpa, endocarpo, cascas e três pastas alimentícias desenvolvidas com polpa e resíduos de Buriti. Além da composição centesimal das frações do fruto e dos preparados, também foram realizadas análises de vitamina $\mathrm{C}$, compostos fenólicos, carotenóides e atividade antioxidante. Foram observados os seguintes valores para as frações do fruto: vitamina C (48,44-55,22 mg/100g), carotenóides $(6,05-21,03$ $\mathrm{mg} / 100 \mathrm{~g})$, fenólicos totais (19,31-33,30 mg GAEq/100g) e atividade antioxidante $(111,24-190,43 \mu \mathrm{mol} \mathrm{TE} / \mathrm{g}$ $\mathrm{DM}$ ), para todos os parâmetros analisados, os maiores valores foram observados para a casca. Quanto às formulações, verificou-se que os bons atributos da casca interferiram na formulação $\mathrm{C}$, que apresentou os maiores rendimentos de vitamina $\mathrm{C}(21,22 \mathrm{mg} / 100 \mathrm{~g})$, carotenóides $(13,99 \mathrm{mg} / 100 \mathrm{~g})$, fenólicos totais $(21,45$ mg GAEq/100 g) e atividade antioxidante (82,34-130,52 $\mu \mathrm{mol}$ TE/g DM). Assim, verifica-se que o buriti possui um grande potencial nutricional para consumo direto ou para ser utilizado na formulação de produtos de confeitaria, incluindo o uso de suas cascas nas formulações.

Palavras-chave: buriti, compostos fenólicos, pasta alimentar

\section{INTRODUÇÃO}

Fruits are important components for a healthy human nutrition, and are usually applied in food formulations, with the aim of providing flavor and nutrients. The Amazon region has an immense variety of fruits, unknown by the rest of the world and with a great potential for industrial use, such as the buriti (Mauritia flexuosa L.) [1]. 
Fruits, such as buriti in general, have their consumption highly recommended for obtaining antioxidant compounds, such as vitamin $\mathrm{C}$, carotenoids and phenolic compounds, notably beneficial to health, since epidemiological studies indicate that a nutrition rich in this fruit, as well as other vegetables, are associated with a lower risk of chronic diseases, due to the presence of an adequate mixture of phytochemicals [2].

In indigenous language, tupi-Guarani language, buriti it means palm that emits liquid, being known by the indigenous as a potential indicator of the presence of water. Currently, this plant is better known as buriti, but it has other names such as: miriti, carandá-guaçú, carandaí-guaçú, muriti, palm-buriti, palm-dos-brejos, mariti, bariti, meriti, it can also be designated as the tree of life, and for scientists it is titled by the scientific name of Mauritia flexuosa L. [3, 4].

All the parts of buriti can be used, from the fruit to the trunk tree and fruit is widely used in food, cosmetics and medicine [5]. The trunk, in the rural area and widely used as raw material in the construction of bridges, ports and rafts. The leaves are used for making "paneiro", "rasa", "matapi", "toy", among others [6].

The fruit is nutritious and has a shape varying from ellipsoid to oblong, covered with corneal scales, the pericarp (or peel), has a reddish-brown color when ripe. The mesocarp (pulp) is thin, yellowish or orange, fleshy and oily. The endocarp of the fruit is composed of a spongy, thin tissue, varying between white and yellowish, with a high cellulose content. The endosperm (or seed) is very hard, ovoid and occupies most of the volume of the fruit $[7,8,9]$.

The extractivism of buriti fruits influences the local economy and culture, and despite having a large consumption in the northern region of Brazil [10]. Its consumption is not carried out in the rest of the country and other parts of the world, but with great potential to be commercialized on a larger scale, fresh or inserted in food formulations.

The consumption of products made for fast consumption and with greater nutritional value has grown a lot, encouraging the development of technologies that allow their manufacture with quality [11]. The use of ready-to-eat paste food is already widespread, due to its microbiological safety and appearance, facilitating the use of fruits as a quick and practical alternative for daily consumption [12].

The buriti presents a great variation in its nutritional composition and is a palm tree present in other parts of South America, with great coverage in the Brazilian territory, mainly in the north of Brazil. It can occur in different biomes with different edaphoclimatic characteristics. In addition to the component macros, buriti also features bioactive compounds. The antioxidant activity of buriti is mainly due to the presence of $\beta$-carotene, which is the main source of vitamin $A$ found in the plant kingdom, in addition to it, the minerals selenium and zinc present in the fruit, also contribute to this beneficial effect [13]. It is a fruit little explored and has culinary and nutritional potential [1].

The buriti fruit contains a high amount of water, protein, lipids and carotenoids, with attractive coloring. Therefore, deteriorating reactions can occur in the product, such as changes in color, flavor, texture and other sensory characteristics. Paste foods result from the proper processing of the disintegrated edible parts of food, with or without the addition of sugars, water, pectin, $\mathrm{pH}$ adjuster, permitted additives and other ingredients to obtain appropriate consistency $[14,15]$.

The key to use Amazonian fruits, such as buriti and its wastes, is to know in scientific way the nutritional and technological benefits that they can offer, in order to insert them in new products and formulations, such as food pastes, adding value to the product and by-products generated and thus strengthening local supply chains in the Amazon region. In this way, this paper verified the physicochemical characteristics, bioactive compounds and antioxidant activity in pulp, endocarp, peels, and three food paste developed with buriti pulp and waste.

\section{MATERIAL AND METHODS}

\subsection{Preparation of raw material}


The fruits (Registration number in SISGEN: A3D580A) were purchased from Abaetetuba City, Pará State, Brazil (Latitude: -1.72951, Longitude: - 48.8743) and were collected during FebruaryMarch 2020. All the ripe fruits (20 Kg of Buriti) in mature stage of reddish-brown color, were left submerged in water for 24 hours to facilitate manual removal of peels, pulp and endocarp. The obtained fractions (Pulp, peels and endocarp) are showed in the Figure 1. The pulp was obtained by scraping the seeds with stainless steel spatulas. All fractions were ground and stored at $-18^{\circ} \mathrm{C}$ until the moment of the analysis.
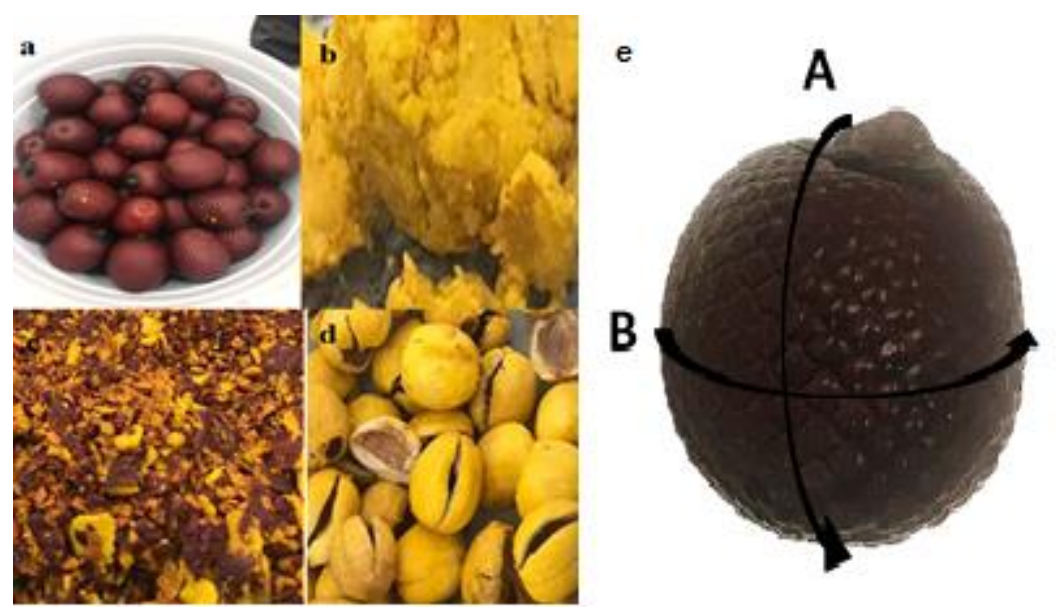

Figure 1: (a) Whole Buriti, (b) Buriti pulp, (c) Buriti peels (waste), (d) Buriti endocarp (waste) and (e) Dimension measurements performed (A and $B)$.

\subsection{Physicochemical characterization}

For the characterization of the physical dimensions of the fruit, the average of the measurements of fruits was used, the following variables were evaluated: mass of the whole fruit (m), length (A) and Width (B), according to the scheme in Figure $1 \mathrm{e}$. The mass variable was obtained with a digital analytical balance, and its results were expressed in grams. Dimension measurements (A and B) were performed using an analog caliper, and the values obtained were recorded in centimeters -30 fruits were used for measurements.

The fruits and formulations were characterized according to $\mathrm{pH}$ with $\mathrm{pH}$ meter (Akso, Brazil), total acidity titratable with $0.1 \mathrm{~N} \mathrm{NaOH}$ solution, moisture by drying in an oven at $105^{\circ} \mathrm{C}$, ash by incineration in a muffle at $550^{\circ} \mathrm{C}$, proteins by the Kjeldahl method, with a correction factor of 6.08 , carbohydrates by difference [16]. Lipids by Bligh and Dyer (1959) [17], total and reducing sugars according to Lane and Eynon (1934) [18]. Vitamin C by Benassi (1990) [19], Water activity with direct measurement in water analyzer water activity (Decagon, model Pawkit, Pullman, USA) [16]. The content of total, soluble and insoluble dietary fibers was determined by the enzymaticgravimetric method [16]. The total energy value (the equation VET $=(\mathrm{Cx} 4)+(\mathrm{Ax} 4)+(\mathrm{Bx} 9)$, where C: carbohydrates, A: total protein and B: ethereal extract) was used.

\subsection{Total phenolic compounds}

The extraction was performed using $(1 \mathrm{~g}$ ) with $20 \mathrm{~mL}$ of ethanol $100 \%$ or water $100 \%$ (two extracts) and were lyophilized. Phenolic compounds were determined by the Folin-Ciocalteu colorimetric method [20]. One gram of crude extracts were used, which were dissolved in $25 \mathrm{~mL}$ of pure water. For the reaction, a aliquot of $250 \mu \mathrm{L}$ was mixed with $1 \mathrm{~mL}$ of the Folin-Ciocalteu reagent and $1 \mathrm{~mL}$ of a $10 \%(\mathrm{w} / \mathrm{v}) \mathrm{Na}_{2} \mathrm{CO}_{3}$ solution and incubated at $30^{\circ} \mathrm{C}$ for $1.5 \mathrm{~h}$. A calibration curve using gallic acid as standard (1.25 to $7.5 \mu \mathrm{g} / \mathrm{mL})$ was used for TP content determination measured at $765 \mathrm{~nm}$ and expressed in $\mathrm{mg} \mathrm{GAEq} / 100 \mathrm{~g}$. 


\subsection{Total carotenoids}

Total carotenoids were measured using the method described by Talcott and Howard (1999) [21], with adaptations. $0.5 \mathrm{~g}$ of sample dissolved in $25 \mathrm{~mL}$ of an acetone-ethanol solution $(1: 1 \mathrm{v} / \mathrm{v})$ were used, mixed and filtered with a paper filter (Whatman Quantitative $\varphi 150 \mathrm{~mm}$ ). The procedure was repeated until the discoloration of sample (approximately 4 times). Then the extract was made up to $100 \mathrm{~mL}$. The absorbance of the extracts was measured at $453 \mathrm{~nm}$ and a calibration curve prepared with a commercial standard of $\beta$-carotene (Sigma), the levels of carotenoids were calculated.

\subsection{DPPH free radical scavenging assay}

The extraction was performed as for total phenolic. The DPPH free radical scavenging activity was evaluated by Macedo et al. (2011) [22], measuring the decrease of the absorbance of an methanolic DPPH solution in the presence of the standard trolox or test samples (extract obtained). For the experiments, the following solutions were prepared: methanol 70\%, DPPH solution (4 $\mathrm{mg}$ in $50 \mathrm{~mL}$ of $\mathrm{MeOH} 50 \%)$, and for Standard trolox curve were prepared two solutions $\left(1^{\circ}-1500\right.$ $\mu \mathrm{mol} / \mathrm{mL}$ and $2^{\circ}-150 \mu \mathrm{mol} / \mathrm{mL}$ ). The reaction mixtures were performed in microplates with of 50 $\mu \mathrm{l}$ of test samples and $150 \mu \mathrm{l}$ of DPPH solution. A NovoStar Microplate reader (BMG LABTECH, Germany) with absorbance filters for an excitation wavelength of $520 \mathrm{~nm}$ was used, and the decolourising process was recorded after 90 min of reaction and compared with a blank control. The DPPH radical-scavenging activity was evaluated by trolox calibration curve. The results were expressed as $\mu$ mol of trolox equivalent per $g$ of dry matter ( $\mu \mathrm{mol} \mathrm{TE} / \mathrm{g} \mathrm{DM})$.

\subsection{Preparation of Buriti paste}

After obtaining the fractions, three food paste formulations were prepared, with the weighing and mixing of the ingredients. Table 1 shows the formulations defined as best according to the texture for confectionery.

Table 1: Formulations used in the preparation of buriti paste (DM).

\begin{tabular}{cccc}
\hline Ingredients (\%) & Formulation A & Formulation B & Formulation C \\
\hline Buriti pulp & 80 & 77 & 77 \\
Crushed peel & 0 & 3 & 0 \\
Crushed endocarp & 0 & 0 & 3 \\
Sugar & 16 & 16 & 16 \\
Cocoa powder & 2 & 2 & 2 \\
Soy lecithin & 2 & 2 & 2 \\
\hline
\end{tabular}

\subsection{Calculations and statistics}

The values were expressed as the arithmetic mean and Tukey test was used to evaluate Statistical significance of the differences between the groups analyzed. Differences were considered significant when $\mathrm{p}<0.05$.

\section{RESULTS AND DISCUSSION}

\subsection{Physicochemical characterization of buriti}

The averages obtained for the mass (m), length (A) and width (B) of the fruit, as well as the standard deviations (SD) and coefficient of variation (CV) are shown in Table 2. Weight was 
verified average of $58.25 \mathrm{~g}$ and $\mathrm{CV}, 0.14 \%$, for the length, a low variation of this parameter was observed, with an average of $5.36 \mathrm{~cm}$ and $\mathrm{CV}$ of $6.90 \%$, indicating a low difference in the results. While the width attribute had an average value of $4.63 \mathrm{~cm}$ and $\mathrm{CV}$ of $4.31 \%$.

Table 2: Results of the physical characterization of buriti.

\begin{tabular}{ccc}
\hline Parameters $^{\mathbf{a}}$ & Average & Coefficient of variation CV (\%) \\
\hline Mass (g) & $58.25 \pm 8.52$ & 0.14 \\
Length (cm) & $5.36 \pm 0.37$ & 6.90 \\
Width (cm) & $4.63 \pm 0.20$ & 4.31 \\
\hline
\end{tabular}

${ }^{a}$ Results are presented as the mean $(n=3) \pm S D$

The results found in this study are similar to the biometric measurements presented by Carvalho and Müller (2005) [23], who in their studies on biometry of Amazonian fruits, estimated in their analysis for buriti, an average mass of $40.5 \mathrm{~g}$, an average length of $5.5 \mathrm{~cm}$ and width of $4.0 \mathrm{~cm}$. Albuquerque and Regiani (2006) [24], estimated an average length of $4.20 \mathrm{~cm}$ and a diameter of $7.35 \mathrm{~cm}$ with an average weight of $32.6 \mathrm{~g}$. Similar data were found by Melo (2008) [25], who observed an average length of $4.65 \mathrm{~cm}$, an average width of $4.41 \mathrm{~cm}$ and an average mass of 44.65 \pm 7.81 . These results are an indication that morphological variation may occur between the fruits of the same region, but this variation would be within a comparable limit, being the result of the phenotypic variability existing within the species.

Table 3 shows the composition of the fruit parts (peduncle, peel, endocarp, pulp and seed) of the buriti, after the processing steps. The seed is the portion that represents the highest percentage $39.16 \%$, the peel and the endocarp, represent 23.56 and $22.34 \%$, the pulp $13.11 \%$ of the total and the peduncle represents $1.11 \%$ of the whole fruit. The evaluation of the residue / pulp ratio showed that the percentage of residues is higher, according to the percentage pulp yield.

Table 3: Nutritional composition of buriti.

\begin{tabular}{cccc}
\hline Determination $^{\mathbf{a}}$ & Pulp (\%) & Endocarp (\%) & Peel (\%) \\
\hline Aw & $0.96 \pm 0.02$ & $0.91 \pm 0.01$ & $0.87 \pm 0.01$ \\
pH & $4.1 \pm 0.06$ & $3.90 \pm 0.01$ & $4.63 \pm 011$ \\
Titratable Acidity (\%) & $7.47 \pm 0.3$ & $13.6 \pm 1.01$ & $4.93 \pm 0.77$ \\
Moisture (\%) & $68.04 \pm 0.04$ & $5.63 \pm 1.93$ & $3.42 \pm 0.27$ \\
Ash (\%) & $0.62 \pm 0.12$ & $3.63 \pm 0.01$ & $6.29 \pm 0.35$ \\
Protein (\%) & $1.66 \pm 0.09$ & $2.70 \pm 0.73$ & $2.16 \pm 0.15$ \\
Lipids (\%) & $11.73 \pm 0.60$ & $14.04 \pm 1.73$ & $3.33 \pm 0.50$ \\
Total Carbohydrates (\%) & $17.89 \pm 0.54$ & $74.24 \pm 0.72$ & $84.8 \pm 1.33$ \\
Total sugar (\%) & $3.69 \pm 0.06$ & $9.36 \pm 0.10$ & $12.85 \pm 1.11$ \\
Reducing sugar (\%) & $2.75 \pm 0.03$ & $5.08 \pm 0.06$ & $8.35 \pm 0.17$ \\
Total Fiber (\%) & $13.90 \pm 2.21$ & $64.24 \pm 1.03$ & $71.80 \pm 2.01$ \\
Insoluble fiber (\%) & $11.25 \pm 1.01$ & $48.68 \pm 1.12$ & $55.60 \pm 0.78$ \\
Soluble fiber (\%) & $1.65 \pm 0.88$ & $15.56 \pm 0.91$ & $16.20 \pm 2.01$ \\
Total energy value TEV (Kcal/100g) & 183.5 & 437 & 377.81 \\
\hline
\end{tabular}

${ }^{a}$ Results are presented as the mean $(n=3) \pm$ SD

Carvalho and Müller (2005) [23], in their studies on the percentage yield of native Amazonian fruit species, presented five categories, based on the pulp yield, with those classified with a percentage below than $20 \%$, as very low yield, for example buriti, which varies between very low and low yield. However, this is not a feature that makes it impossible to use this fruit, as other parts can be used to obtain a better use. The results of this study are equivalent to found by Melo (2008) [25], Becker et al. (2006) [26], Martins (2010) [27] and Barbosa, Lima and Júnior (2007) [28], who found similar percentages for peel, seed and endocarp, with the exception of pulp. 
The results of the composition of the buriti are shown in Table 3. The pulp showed average moisture values of 68.04\%, this result is similar to found by Tavares et al. (2003) [29], (67.2\%) and Manhães (2007) [30], with the percentage of $62.93 \%$ in the pulp, however different from that found by Carneiro and Carneiro (2011) [31], with the 54.34\%.

The $\mathrm{pH}$ found for the pulp was 4.1 and was similar to that shown by Martins (2010) [27], who obtained a $\mathrm{pH}$ of 3.38. The total acidity value of the pulp was $7.47 \%$, being lower than that verified by Martins (2010) [27], which was 13.46 . The percentage of pulp ash was $0.62 \%$, similar to observed by Castro et al. (2014) [32] and Manhães (2007) [30], (1.05 \pm 0.16 and $0.94 \pm 0.06$ ).

The protein value of the buriti pulp was $1.66 \%$, consistent with the values found by Carneiro and Carneiro (2011) [31], Tavares et al. (2003) [29] and the Brazilian Institute of Geography and Statistics (IBGE) (2011) [33], 1.30\%, 1.5\% and 1.80\% respectively. In this work, the lipid content of lipids for the pulp was $11.73 \%$, similar to the value presented by Manhães (2007) [30], 13.85\%, and higher than that found by IBGE (2011) [33], 8, 10\%. While the result for carbohydrate was $17.89 \%$, higher than that presented by Tavares et al. (2003) [29] 12.1\% and Manhães (2007) [30] $8.25 \%$.

The total fiber yields found in the pulp, endocarp and peel were $13.90 \%, 64.24 \%$ and $71.80 \%$ respectively, with the highest value observed for peel, followed by endocarp, which demonstrates an important attribute for justify the use of both materials in food formulations, due to the health benefits they can offer in terms of fibers. Endocarp was the fraction that showed the highest yield of lipid (14.04\%) and the peel was the lowest (3.33\%), according to Richter and Lannes (2007) [34], this component has a great influence on the final texture of products confectionery. Endocarp and peel showed higher protein values when (2.70 and $2.16 \%)$ compared to pulp, which means that the addition of these components in food pastes would be an alternative to supplement in terms of protein, confectionery, notably rich in carbohydrates.

The total sugar yields for the fractions ranged from 3.69 to $12.85 \%$, and for reducing sugars from 2.75 to $8.35 \%$, the peel presented the highest values for both, which means lower costs with the need to add sugar in this type of formulation. Sandri et al. (2017) [35], found lower values for the buriti endocarp, with values of $7.28 \%$ for total sugars and $4.50 \%$ for reducing sugars. The total energy value was one of the parameters that most showed variance in the analyzed literature [29, $30,31,33$ ] and were 183.5, 437 and 377.81 (Kcal/g) for the pulp, endocarp and peel respectively.

Table 4 shows the results obtained for bioactive compounds and antioxidant activity in the buriti fractions. The peel was the fraction that showed the highest yields of vitamin $C(55.22 \mathrm{mg} / 100 \mathrm{~g})$, carotenoids $(21.03 \mathrm{mg} / 100 \mathrm{~g})$ and Total phenolics $(33.30 \mathrm{mg}$ GAEq/100g) respectively. After the peel, the endocarp showed the best results for vitamin $\mathrm{C}$ and (TPs).

Table 4: Bioactive compounds and antioxidant activity for buriti fractions.

\begin{tabular}{cccc}
\hline Determination & Pulp & Endocarp & Peel \\
\hline Vitamin C (mg/100g) & $51.33 \pm 1.05$ & $48.44 \pm 0.99$ & $55.22 \pm 2.10$ \\
Carotenoid (mg/100g) & $9.28 \pm 0.04$ & $6.05 \pm 1.04$ & $21.03 \pm 0.94$ \\
Total phenolics (TPs) (mg GAEq/100g) & $19.31 \pm 0.93$ & $29.32 \pm 0.93$ & $33.3 \pm 0.73$ \\
Antioxidant Activity (Ethanol)( $\boldsymbol{\mu m o l ~ T E / g ~ D M ) ~}$ & $160.11 \pm 0.76$ & $150.10 \pm 0.35$ & $190.43 \pm 1.55$ \\
Antioxidant Activity $\left(\mathbf{H}_{\mathbf{2}} \mathbf{O}\right)(\boldsymbol{\mu m o l ~ T E} / \mathbf{g}$ DM) & $113.33 \pm 0.13$ & $111.24 \pm 0.34$ & $120.45 \pm 0.44$ \\
\hline
\end{tabular}

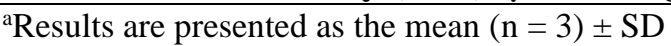

The antioxidant activity ranged from 111.24-190.43 $\mu \mathrm{mol}$ TE/g DM, and the pulp value was higher than values found by Gonçalves, Lajolo and Genovese (2010) [36] (20 $\mu \mathrm{mol} \mathrm{of} \mathrm{TE/g)} \mathrm{and}$ by Candido, Silva and Agostini-Costa (2015) [37] (123.28 $\pm 3.77 \mu \mathrm{mol}$ of TE/g), which can be explained by different origins of buriti [37], and by extraction methodology used. The values found for the pulp in this work were higher than that reported in a study for exotic Brazilian fruits, such as cattley guava (Psidium guineensis Sw.) $(4.1 \mu \mathrm{mol} \mathrm{TE} / \mathrm{g})$ and jaracatiá (Jaracatia spinosa DC) (4.4 $\mu \mathrm{mol}$ of $\mathrm{TE} / \mathrm{g})$ [38]. The buriti peel was the fraction that demonstrated higher values of antioxidant activity for both extractions performed (120.45-190.43 $\mu \mathrm{mol}$ of TE/g), which can be explained by the high values of bioactive compounds in this fraction, and justify the use of this 
fraction in confectionery products, convenient and source of bioactive compounds with antioxidant properties.

Buriti has a variety of carotenoids, which vary according to the place of harvest, temperature and solar radiation [1]. High temperatures and high solar incidence improve the yield of carotenoids in the buriti, which is observed in the Amazon region [39].

The bioactive compounds present in buriti, can provide health benefits, mainly due to their antioxidant activity, capable of promoting inhibitory effects against oxidative stress, preventing the appearance of diseases such as cancer and neurodegenerative diseases [5]. In addition, the presence of phenolic compounds shows an anti-inflammatory effect, reducing the risk of developing cardiovascular diseases [1]. Thus, the complete use of buriti is justified by the significant presence of bioactive compounds and antioxidant activity in all analyzed fractions of the fruit, presented in this work, which stimulates the creation of new products and by-products, responsible for expanding its use by the industry to obtaining foods beneficial to human health, such as the food paste. The Table 5 presents the results obtained for the chemical composition of the developed buriti food pastes.

Table 5: Nutritional composition of the developed food pastes.

\begin{tabular}{cccc}
\hline Determination $^{\mathrm{a}}$ & Formulation A & Formulation B $^{\text {Formulation C }}$ \\
\hline Aw & $0.86 \pm 0.01^{\mathrm{b}}$ & $0.81 \pm 0.01^{\mathrm{a}}$ & $0.83 \pm 0.01^{\mathrm{a}}$ \\
pH (25 $\mathbf{C})$ & $4.33 \pm 0.05^{\mathrm{a}}$ & $4.0 \pm 0.01^{\mathrm{b}}$ & $4.16 \pm 0.11^{\mathrm{a}}$ \\
Titratable Acidity (\%) & $11.69 \pm 0.86^{\mathrm{a}}$ & $11.36 \pm 0.76^{\mathrm{a}}$ & $10.16 \pm 0.05^{\mathrm{b}}$ \\
Moisture (\%) & $46.33 \pm 0.12^{\mathrm{a}}$ & $42.89 \pm 0.66^{\mathrm{b}}$ & $45.18 \pm 3.31^{\mathrm{a}}$ \\
Ash (\%) & $1.38 \pm 0.23^{\mathrm{a}}$ & $1.23 \pm 0.10^{\mathrm{a}}$ & $0.80 \pm 0.27^{\mathrm{b}}$ \\
Protein (\%) & $2.75 \pm 0.10^{\mathrm{c}}$ & $3.4 \pm 0.41^{\mathrm{a}}$ & $3.1 \pm 0.25^{\mathrm{b}}$ \\
Lipids (\%) & $13.99 \pm 0.34^{\mathrm{a}}$ & $17.72 \pm 0.90^{\mathrm{b}}$ & $13.65 \pm 0.12^{\mathrm{a}}$ \\
Total Carbohydrates (\%) & $36.21 \pm 0.98^{\mathrm{b}}$ & $34.76 \pm 0.98^{\mathrm{c}}$ & $37.27 \pm 098^{\mathrm{a}}$ \\
Total sugar (\%) & $12.79 \pm 0.54^{\mathrm{a}}$ & $11.32 \pm 1.10^{\mathrm{b}}$ & $12.50 \pm 2.43^{\mathrm{a}}$ \\
Reducing sugar (\%) & $9.23 \pm 0.28^{\mathrm{a}}$ & $6.83 \pm 0.20^{\mathrm{b}}$ & $9.29 \pm 0.37^{\mathrm{a}}$ \\
Total fiber (\%) & $20.55 \pm 0.05^{\mathrm{b}}$ & $21.44 \pm 1.08^{\mathrm{b}}$ & $24.07 \pm 1.43^{\mathrm{a}}$ \\
Insoluble fiber (\%) & $15.77 \pm 1.33^{\mathrm{c}}$ & $18.45 \pm 0.98^{\mathrm{b}}$ & $19.01 \pm 0.45^{\mathrm{a}}$ \\
Soluble fiber (\%) & $4.78 \pm 1.21^{\mathrm{b}}$ & $4.99 \pm 0.44^{\mathrm{a}}$ & $5.06 \pm 1.15^{\mathrm{a}}$ \\
Total energy value TEV (Kcal/100g) & 281.75 & 312.12 & 284.33 \\
\hline
\end{tabular}

Formulation A (with only pulp); Formulation B (with pulp and endocarp); Formulation C (with pulp and peels); ${ }^{a}$ Results are presented as the mean $(\mathrm{n}=3) \pm \mathrm{SD}$, and those with different letters are significantly different, with $p<0.05$ );

Aw for food pastes ranged from 0.81-0.86, with formulation B being the lowest and which can be classified by Chirife and Buera (1994) [40], as intermediate moisture foods, with relative stability. Formulation B presented the highest yields of protein $(3.40 \%)$ and lipids $(17.72 \%)$, differing $(\mathrm{p}<0.05)$ in relation to formulations $\mathrm{A}$ and $\mathrm{C}$, for both components. The highest yield of total fibers $(24.07 \%)$ was observed in formulation C, obtained with bark, which is significantly different from the others.

Formulation B, showed the second highest value for total fibers $(21.44 \%)$, which can be explained by the fact that the peels and endocarp, were the fractions of the fruits with the highest values for this component, according to the present work. Formulation $\mathrm{C}$ showed the highest yield of insoluble fibers, being statistically different at $5 \%$ in the T test compared to the others. The high yield of lipid and protein, observed for formulation B, contributed to its high value of Total energy value $(312.12 \mathrm{Kcal} / 100)$ in relation to the others.

Unlike this work, Lima and Duarte (2006) [41], did not observe significant differences for yields of moisture, ash, $\mathrm{pH}$, titratable acidity and carbohydrates, between formulations of cashew nut paste. The yields of protein and lipids obtained in this work were lower than those found by Lima and Bruno (2007) [42], and Lima and Duarte (2006) [41], both for cashew nut paste, however they 
were similar to those obtained by Arévalo-Pinedo et al. (2010) [12], who developed a formulation of pequi (Caryocar brasiliense) paste.

Table 6 shows bioactive compounds and antioxidant activity found for the formulations developed. The highest yield of vitamin $C$ was found for formulation $C(21.22 \mathrm{mg} / 100 \mathrm{~g})$, with no statistical difference $(\mathrm{p}<0.05)$ in relation to formulation A $(20.12 \mathrm{mg} / 100 \mathrm{~g})$. Formulation C was also the one that showed the highest values of Carotenoid $(13.99 \mathrm{mg} / 100 \mathrm{~g})$ and Total phenolic (21.45 mg GAEq/100g), which directly influenced its higher antioxidant activity value when compared to the others (80.44- $130.52 \mu \mathrm{mol}$ TE/g DM).

Table 6: Bioactive compounds and antioxidant activity for developed food pastes.

\begin{tabular}{|c|c|c|c|}
\hline Determination $^{\mathbf{a}}$ & $\begin{array}{c}\text { Formulation } \\
\text { A } \\
\end{array}$ & $\begin{array}{c}\text { Formulation } \\
\text { B } \\
\end{array}$ & $\begin{array}{c}\text { Formulation } \\
\mathrm{C} \\
\end{array}$ \\
\hline Vitamin C (mg /100g) & $20.12 \pm 1.05^{\mathrm{b}}$ & $19.13 \pm 0.99^{c}$ & $21.22 \pm 1.20^{\mathrm{a}}$ \\
\hline Carotenoid (mg/100g) & $7.01 \pm 1.01^{\mathrm{a}}$ & $6.48 \pm 0.34^{\mathrm{a}}$ & $13.99 \pm 2.01^{\mathrm{b}}$ \\
\hline Total phenolic (TP) (mg GAEq/100g) & $13.33 \pm 0.34^{\mathrm{b}}$ & $16.84 \pm 1.05^{\mathrm{b}}$ & $21.45 \pm 0.99^{\mathrm{a}}$ \\
\hline Antioxidant Activity (Ethanol) $(\mu \mathrm{mol}$ TE/g DM) & $100.45 \pm 11.55^{\mathrm{a}}$ & $80.44 \pm 5.76^{\mathrm{b}}$ & $130.52 \pm 5.35^{\mathrm{c}}$ \\
\hline Antioxidant Activity $\left(\mathrm{H}_{2} \mathrm{O}\right)(\mu \mathrm{mol} \mathrm{TE} / \mathrm{g} \mathrm{DM})$ & $70.81 \pm 2.84^{\mathrm{a}}$ & $51.55 \pm 0.84^{\mathrm{b}}$ & $82.34 \pm 1.66^{\mathrm{c}}$ \\
\hline
\end{tabular}

Formulation A (with only pulp); Formulation B (with pulp and endocarp); Formulation C (with pulp and peels); ${ }^{a}$ Results are presented as the mean $(n=3) \pm S D$, and those with different letters are significantly different, with $\mathrm{p}<0.05$ );

The use of the peel (formulation C) allowed an average increase of $23.10 \%$ in antioxidant activity, compared to formulation A (pulp only), however the use of endocarp had the opposite effect, with a reduction of $31.11 \%$. It is important to highlight that the endocarp of buriti is a waste, currently not used in food formulations, and that presented values of bioactive compounds, similar to pulp, strengthening the possibility of its technological use. It was observed that the use of endocarp in formulation $\mathrm{B}$, generated a higher yield of phenolic compounds compared to formulation A, but without significant difference $(\mathrm{p}<0.05)$ and that alcoholic extractions allowed a maximum increase of $58.09 \%$ in antioxidant activity compared to aqueous extractions.

\section{CONCLUSION}

It is possible to conclude that buriti and its residues have interesting nutritional values, with special attention to insoluble fibers and their bioactive compounds, especially carotenoids and phenolic compounds. It was also verified that both the buriti pulp and the evaluated residues allowed to obtain confectionery products with attractive contents of bioactive compounds and antioxidant activity, thus creating a healthy alternative of food paste with added technological and commercial value to little-known Amazonian fruits and consumed.

\section{REFERENCES}

1. Freire PJA, Barros KBNT, Lima LKF, Martins JM, Araújo YC, Oliveira GLS, Aquino JS, Ferreira PMP. Phytochemistry profile, nutritional properties and pharmacological activities of Mauritia flexuosa. J Food Sci. 2016;81(11):2611-2622, doi: 10.1111/1750-3841.13529.

2. Monteiro CS. Desenvolvimento de molho de tomate Lycopersicon esculentum Mill formulado com cogumelo Agaricus brasiliensis [PhD thesis]. Curitiba (PR): Universidade Federal do Paraná; 2008. 176 p.

3. Sampaio MB. Boas práticas de manejo para extrativismo sustentável do buriti. Brasília: Instituto Sociedade, População e Natureza; 2011. 80 p.

4. Vieira RF, Costa TSA, Dijalma BS, Francisco RF, Sueli MS. Frutas nativas da região centro oeste do Brasil. 1. ed. Brasília: Embrapa Recursos Genéticos e Biotecnologia; 2006. 102 p.

5. Koolen HH, da Silva FM, Gozzo FC, de Souza AQ, de Souza AD. Antioxidant, antimicrobial activities and characterization of phenolic compounds from buriti (Mauritia flexuosa L. f.) by UPLC-ESI-MS/MS. Food Res Int. 2013;51(2):467-473, doi: 10.1016/j.foodres.2013.01.039. 
6. Santos RS, Coelho-Ferreira MC. Estudo etnobotânico de Mauritia flexuosa L. F. (Arecaceae) em comunidades ribeirinhas do município de Abaetetuba, Pará, Brasil. Rev Acta Amazônica. 2012;42(1):1 10, doi: 10.1590/S0044-59672012000100001.

7. Spera MRN, Cunha R, Teixeira JB. Quebra de dormência, viabilidade e conservação de sementes de buriti (Mauritia flexuosa). Pesq Agropec Bras. 2001;36(12):1567-1572, doi: 10.1590/S0100204 X2001001200015.

8. Sampaio MB, Carrazza LR. Manual tecnológico de aproveitamento integral do fruto e da folha do buriti (Mauritia flexuosa). Brasília: Instituto Sociedade, População e Natureza; 2012. 76 p.

9. Sales VF. Importância da preservação, potencial e viabilidade para exploração econômica de frutos de buriti [monography]. Brasília (DF): Faculdade de Agronomia e Medicina Veterinária da Universidade de Brasília; 2016. 48 p.

10. Cunha MAE, Neves RF, Souza JNS, França LF, Araújo ME, Brunner G, Machado NT. Supercritical adsorption of buriti oil (Mauritia flexuosa Mart.) in $\gamma$-alumina: A methodology for the enriching of antioxidants. J Supercritical Fluids. 2012;66:181-191, doi: 10.1016/j.supflu.2011.10.021.

11. Berbari SAG, Silveira NFA, Oliveira LAT. Avaliação do comportamento de pasta de alho durante o armazenamento (Allium Satium L.). Rev Food Sci Technol. 2003;23(3):468-472, doi: 10.1590/S010120612003000300029.

12. Arévalo-Pinedo A, Maciel VBV, Carvalho KM, Coelho AFS, Giraldo-Zuñiga AD, Arévalo ZDS, et al. Processamento e estudo da estabilidade de pasta de pequi (Caryocar brasiliense). Rev Food Sci Technol. 2010;30(3):664-668, doi: 10.1590/S0101-20612010000300015.

13. Moura Filho JM de. Preparado de buriti (Mauritia flexuosa L): produção, caracterização e aplicação em leite fermentado [PhD thesis]. São José do Rio Preto (SP): Instituto de Biociências Exatas da Universidade Estadual Paulista; 2017. 124 p.

14. Oliveira MEB, Lima AC, Rocha LS, Santos GS, Mesquita SA, Moreira RL. Processo agroindustrial: Elaboração de pasta de pequi [Comunicado Técnico 190]. Fortaleza (CE): Embrapa Agroindústria Tropical; 2012. 5 p.

15. Lovatto MT. Agroindustrialização de frutas I. Santa Maria: Universidade Federal de Santa Maria, Colégio Politécnico, Rede e-Tec Brasil; 2016. 98 p.

16. Association of Official Analytical Chemists. Official methods of analysis. 17th ed. Washington (DC): AOAC; 2002. 1835 p.

17. Bligh EG, Dyer WJ. A rapid method of total lipid and purifi cation. Rev Can J Biochem Physiol. 1959;37(8):911-917.

18. Lane JH, Eynon L. Determination of reducing sugars by Fehling's solution with methylene blue indicator. London: Normam Rodge; 1934.8 p.

19. Benassi MT. Análise dos efeitos de diferentes parâmetros de vitamina C em vegetais processados. [master's dissertation]. Campinas (SP): Universidade Estadual de Campinas, Faculdade de Engenharia de Alimentos; 1990. 159 p.

20. Singleton VL, Orthofer R, Lamuela-Raventós RM. Analysis of total phenols and other oxidation substrates and antioxidants by means of folin-ciocalteu reagent. Methods in Enzymology. 1999;299:152178, doi: 10.1016/S0076-6879(99)99017-1.

21. Talcott ST, Howard DLR. Phenolic autoxidation is responsible for color degradation in orocessed carrot puree. J Agric Food Chem. 1999;47:2109-2115, doi: 10.1021/jf981134n.

22. Macedo JA, Battestin V, Ribeiro ML, Macedo GA. Increasing the antioxidant power of tea extracts by biotransformation of polyphenols. Food Chem. 2011;126:491-497, doi: 10.1016/j.foodchem.2010.11.026.

23. Carvalho JEU, Müller CH. Biometria e rendimento percentual de polpa de frutas nativas da Amazônia [Comunicado Técnico 139]. Belém (PA): Embrapa Amazônia Oriental; 2005. 3 p.

24. Albuquerque SRS, Regiani AM. Estudo do fruto do buriti (Mauritia flexuosa) para obtenção de óleo e síntese de biodiesel. In: Proceedings of the 29a Reunião Anual da Sociedade Brasileira de Química; 2006; Águas de Lindóia, São Paulo, Brasil. 2006. CD-Rom.

25. Melo WS. Avaliação Tecnológica da potencialidade do fruto buriti (Mauritia flexuosa) [master's dissertation]. Belém (PA): Universidade Federal do Pará; 2008. 74 p.

26. Becker MM, Santos VRS, Flach A, Costa LAMA. Avaliação do potencial do buritizeiro para produção de Biodiesel no Estado de Roraima. 29a Reunião Anual da Sociedade Brasileira de Química; 2006; Águas de Lindóia, São Paulo, Brasil. 2006. CD-Rom.

27. Martins ML. Fenologia, produção e pós-colheita de frutos de buriti (Mauritia flexuosa Lf) em três veredas do cerrado no estado de Goiás [master's dissertation]. Goiânia (GO): Universidade Federal de Goiás; 2010. 144 p. 
28. Barbosa RI, Lima AD, Júnior MM. Biometria de frutos do buriti (Mauritia flexuosa LF-Arecaceae): produção de polpa e óleo em uma área de savana em Roraima. Amazônia: Ci \& Desenv. 2007;5(10):7185.

29. Tavares M, Aued-Pimentel S, Lamardo LC, Campos NC, Jorge LI, Gonzalez E. Composição química e estudo anatômico de frutos de buriti do município de Buritizal, estado de São Paulo. Rev Inst Adolfo Lutz. 2003;62(3):227-232.

30. Manhães LRT. Caracterização da polpa de buriti (Mauritia flexuosa, Mart.): Um potente alimento funcional [master's dissertation]. Rio de Janeiro (RJ): Universidade Federal Rural do Rio de Janeiro; 2007. $78 \mathrm{p}$.

31. Carneiro TB, Carneiro JGM. Frutos e polpa desidratado buriti (Mauritia flexuosa L.): aspectos físicos, químicos e tecnológicos. Rev Verde Agroecol Desenv Sustent. 2011 Abr/Jun;6(2):105-111.

32. Castro DSD, Sousa EPD, Nunes JS, Silva LMDM, Moreira IDS. Caracterização física e físico-química de polpa de buriti (Mauritia flexuosa). Rev Verde Agroecol Desenv Sustent. 2014;9(2):117-120.

33. Instituto Brasileiro de Geografia e Estatística. Pesquisa de orçamentos familiares 2008-2009: Tabelas de Composição Nutricional dos Alimentos Consumidos no Brasil. Rio de Janeiro: IBGE; 2011. 350 p.

34. Richter M, Lannes, SCS. Ingredients used in the chocolate industry. Rev Bras Cienc Farm. 2007;43(3):357-369, doi: 10.1590/S1516-93322007000300005.

35. Sandri DO, Xisto ALRP, Rodrigues EC, Morais EC, Barros WM. Atividade antioxidante e características físico-químicas da polpa de buriti (Mauritia flexuosa) coletada na cidade de Diamantina-MT. Rev Brasileira de Fruticultura. 2017;39(3):e-864, doi: 10.1590/0100-29452017864.

36. Gonçalves ANSS, Lajolo FM, Genovese MI. Chemical composition and antioxidant/antidiabetic potential of Brazilian native fruits and commercial frozen pulps. J Agric Food Chem. 2010;58(8):4666-4674, doi: 10.1021/jf903875u.

37. Candido TLN, Silva MR, Agostini-Costa TS. Bioactive compounds and antioxidant capacity of buriti (Mauritia flexuosa L.f.) from the Cerrado and Amazon biomes. Rev Food Chem. 2015; 177:313-319, doi: 10.1016/j.foodchem.2015.01.041.

38. Genovese MI, Pinto MS, Gonçalves AESS, Lajolo FM. Bioactive compounds and antioxidant capacity of exotic fruits and commercial frozen pulps from Brazil. Food Sci Technol Int. 2008;14:207-214, doi: $10.1177 / 1082013208092151$.

39. Rudke AR, Mazzutti S, Andrade KS, Vitali L, Ferreira, SRS. Optimization of green PLE method applied for the recovery of antioxidant compounds from buriti (Mauritia flexuosa L.) Shell. Food Chem. 2019;298(15):125061, doi: 10.1016/j.foodchem.2019.125061.

40. Chirife J, Buera MDP. Water activity, glass transition and microbial stability in concentrated/semimols food systems. J. Food Sci. 1994;59(5):925-927, doi: 10.1111/j.1365-2621.1994.tb08159.x.

41. Lima JR, Duarte EA. Pastas de castanha-de-caju com incorporação de sabores. Pesq Agropec Brasil. 2006;41(8):1333-1335, doi: 10.1590/S0100-204X2006000800019.

42. Lima JR, Bruno LM. Estabilidade de pasta de amêndoa de castanha de caju. Ciênc Tecnol Aliment. 2007;27(4):816-822, doi: 10.1590/S0101-20612007000400023. 